\title{
Removing Rulers in the Niger Delta, I887-I897
}

By the mid I 88 os, Britain had joined the 'scramble for Africa'. The European powers were now not simply seeking to open up trade with African rulers, but to make exclusive territorial claims. With a framework established at the Berlin Conference for how imperial powers could claim territory on the West African coast, each of them hurried to assert their rights in particular areas. ${ }^{\text {I }}$ In contrast to her European neighbours, Britain did not wish to annex large swaths of new territory as colonies, both because of the potential expense involved and because of the legal problems presented by making British subjects of people who still practised slavery. However, in the context of intense territorial competition between the European powers, the traditional English conception of protectorates came under pressure. In an era when both diplomats and international lawyers were increasingly viewing African polities as lacking the capacity to be actors on the international stage, the British notion that protectorates were at base relationships founded on treaty obligations gradually gave way to the view held by the other European powers that

I On the Berlin conference and the scramble, see Ronald Robinson and John Gallagher, Africa and the Victorians: The Official Mind of Imperialism, 2nd ed. (London, MacMillan, I98I); S. Crowe, The Berlin West African Conference I884-I885 (London, Longmans Green \& Co., I942); and S. Förster, W. Mommsen and R. Robinson (eds.), Bismarck, Europe and Africa: The Berlin Africa Conference I884-I885 and the Onset of Partition (Oxford, Oxford University Press, I988). 
protection was a form of imperial control. ${ }^{2}$ At the same time, the traditional British distinction between colonies and protectorates was not effaced, so the exact position of those living under British protection would remain ambiguous.

In the decade after the Berlin conference, as Britain's interest in the region of the Oil Rivers in the Niger delta increased, so the imperial authorities encountered a number of rulers who stood in the way of their economic ambitions. These rulers signed treaties with the British and so came under their 'sphere of influence' - but sought to maintain a level of control in their regions which the new imperial power could not accept. Between I 887 and I897, Britain removed three rulers in this area, the detention of each of whom would - at least eventually be formally regularized by an ad hominem ordinance. In this region, the responsible department in Whitehall dealing with the detentions was not the Colonial Office, but the Foreign Office, since treaties of protection came within the remit of foreign policy rather than colonial administration. Officials here were less punctilious about the legal basis of detention than their counterparts at the Colonial Office; for they could leave it to the colonial authorities to pass the necessary legislation when detainees were removed to a colony. At the same time, they sought to lay foundations for the detentions they ordered by holding quasi-legal inquiries of the sort generally eschewed in the Gold Coast and Sierra Leone. Although these inquiries always fell far short of the due process requirements of the rule of law, they were intended to justify the actions taken against these rulers both to domestic audiences and to African ones. As shall be seen, the nature of the inquiry used also changed over time, as the particular rulers provided for were increasingly regarded as subject to British power rather than being independent rulers.

${ }^{2}$ On the development of a notion of territorium nullius which denied that African rulers could hold territorial sovereignty, although they had the capacity to alienate their property rights, see Andrew Fitzmaurice, Sovereignty, Property and Empire, I 500-2000 (Cambridge, Cambridge University Press, 20I4), ch. 9. See further Antony Angie, Imperialism, Sovereignty and the Making of International Law (Cambridge, Cambridge University Press, 2005); Jennifer Pitts, Boundaries of the International: Law and Empire (Cambridge, Harvard University Press, 20I8); and W. Ross Johnston, Sovereignty and Protection: A Study of British Jurisdictional Imperialism in the Late Nineteenth Century (Durham, Duke University Press, I973). 


\section{The British Presence in the Oil Rivers}

In contrast to the Gold Coast and Sierra Leone, there were no formal colonial settlements on the Bights of Benin and Biafra, though the British had long traded along this coast. ${ }^{3}$ British official presence in the region was limited to consular representation. In I849, John Beecroft was appointed consul, tasked with promoting legitimate trade and preventing the 'frequent misunderstandings' which arose between coastal chiefs and British merchants. ${ }^{4}$ As part of this mission, he encouraged the creation of informal courts of equity to resolve commercial disputes. ${ }^{5}$ Regarded as a 'quasi-protectorate' during the I850s, with its own permanent consul, Lagos was formally ceded to the crown in I86r ${ }^{6}$ Courts of equity were also set up further down the coast in the Niger River Delta by the consul responsible for the Bight of Biafra. The British obtained more formal powers in $\mathrm{I} 872$, when an Order in Council gave the consul jurisdiction

3 See Martin Lynn, Commerce and Economic Change in West Africa: The Palm Oil Trade in the Nineteenth Century (New York, Cambridge University Press, I997); Robin Law (ed.), From Slave Trade to 'Legitimate' Commerce: The Commercial Transition in Nineteenth-Century West Africa (New York, Cambridge University Press, 1995); Michael Crowder, West Africa under Colonial Rule (London, Hutchinson, I968); K. O. Dike, Trade and Politics in the Niger Delta, I830-I885 (Oxford, Oxford University Press, I956); G. I. Jones, The Trading States of the Oil Rivers: A Study of Political Development in Eastern Nigeria (London, Oxford University Press, I963); G. I. Jones, From Slaves to Palm Oil: Slave Trade and Palm Oil Trade in the Bight of Biafra (Cambridge, African Studies Centre, I989); J. D. Hargreaves, Prelude to the Partition of West Africa (London, Macmillan, I963); J. D. Hargreaves, West Africa Partitioned (Madison, University of Wisconsin Press, I974); and W. D. McIntyre, The Imperial Frontier in the Tropics, I865-75 (New York, St. Martins Press, I967).

4 See Martin Lynn, 'Britain's West African Policy and the Island of Fernando Po, I82I-43', The Journal of Imperial and Commonwealth History, vol. I 8:2 (I990), pp. I9I-207; and K. O. Dike, 'John Beecroft, I790-I 854: Her Britannic Majesty's Consul to the Bights of Benin and Biafra, I 849-1 854', Journal of the Historical Society of Nigeria, vol. I:I (I956), pp. 5-I4.

5 Martyn Lynn, 'Law and Imperial Expansion: The Niger Delta Courts of Equity, $c$. I 850-85', The Journal of Imperial and Commonwealth History, vol. 23: ( (1995), pp. 54-76. Beecroft also intervened in local polities periodically, playing a part in unseating both King Kosoko of Lagos and King Pepple of Bonny: Robert Smith, 'The Lagos Consulate, I 85 I-I 86I: An Outline', Journal of African History, vol. I 5:3 (I974), pp. 3I3-4I6 at pp. 397-399; and Toyin Falola and Matthew M. Heaton, A History of Nigeria (Cambridge, Cambridge University Press, 2008), p. 97.

${ }^{6}$ See PP I862 (2982) LXI. 339. 
in the Oil Rivers area over British subjects, those enjoying British protection and foreigners who consented to it. ${ }^{7}$ It also gave him power to reorganise the courts of equity, which were to be regarded henceforth effectively as consular courts. The extraterritorial jurisdiction thus regulated was assumed to come from African sufferance rather than treaty, though the Oil Rivers area over which it extended was not at this stage regarded as a protectorate or in any way under British sovereignty. ${ }^{8}$

At the beginning of the I870s, the consular district extended from the border of the Lagos colony to Carisco Bay, south of the Cameroons. Although the level of active British involvement remained small, by the early $\mathrm{I} 88 \mathrm{os}$ British officials were increasingly worried by the interest shown by other European powers in the area. The British consul, Edward Hewett, was particularly concerned about French ambitions in the Cameroons - whose chiefs had petitioned for an 'English government' in I879 - and argued in favour of placing the whole region 'under British rule', whether as a colony or protectorate or under a chartered company. 9 This idea elicited different reactions from different departments. While the Colonial Office opposed any plan which would increase the government's responsibilities in West Africa, ${ }^{10}$ the Foreign Office felt that, if the Cameroons' 'formal offer of cession' were turned down, the French would step in. The policy agreed at the end of 1883 was that the request of the rulers of the Cameroons for some form of British administration should be accepted. This would not take the form of a colony, ${ }^{\text {II }}$ but rather there should be British sovereignty over a half-mile-wide strip of the coastline, and 'protection should be extended' inland as far as was necessary to fulfil the treaty engagements with the rulers. ${ }^{\mathrm{I} 2}$ A treaty of protection was duly drafted. ${ }^{\mathrm{I} 3}$ As for the Lower Niger and Oil Rivers area, the Foreign Office wanted nothing more than an extended consular jurisdiction over crime and trade disputes, effected by treaties with

\footnotetext{
7 London Gazette, 27 February I872, p. 762.

8 Johnston, Sovereignty and Protection, pp. 66-69. 9 FO 403/I 8, No. I, p. I; No. 9, p. 20.

Io $\mathrm{FO} 403 / \mathrm{I} 8$, No. 22, p. 28 . II Meade to Pauncefote, 5 January I 884, FO 84/I68 I, f. I.

I2 Note 2 I November I883, FO 84/I655, f. 309. 'I3 Draft treaty, FO 84/I68 I, f. I7.
} 
local chiefs 'acknowledging a nominal Protectorate of England, and binding them not to cede any land to any other Government'. ${ }^{\text {I }}$

In order to execute this policy, in May I 884, Hewett was sent first to conclude treaties with chiefs in the Niger and Oil Rivers areas, ${ }^{\mathrm{I}}$ before moving on to the Cameroons. The printed treaties Hewett took followed a standard form. They extended the Queen's 'gracious favour and protection' to the signatory kings, who promised not to enter into any agreements with foreign powers without British assent and to allow free trade. They stipulated that the kings were to act on the consul's advice on matters of justice, good government and commerce. ${ }^{16}$ The treaties also gave consular officials extraterritorial jurisdiction over British subjects and 'foreign subjects enjoying British protection', and provided that the consular authorities would settle any disputes (such as between the signatory kings and British or foreign traders). ${ }^{17}$ At the same time that Hewett was signing treaties, the chief agent of the National Africa Company, David McIntosh (who was himself appointed a Vice-Consul on the Niger), also began to sign treaties with African rulers, which went further, in that the chiefs ceded 'the whole of their territories' to the company, as well as promising not to trade with foreign powers without the company's approval. ${ }^{18}$ Hewett's plan to go on to the Cameroons and bring them under British protection failed, however, when he was beaten in the race to offer their rulers a treaty by the German ConsulGeneral. ${ }^{\text {19 }}$

${ }^{14}$ Memorandum by T. V. Lister, 24 October I 88 3 , FO 84/I655, f. 25 ; FO 403/I9, No. 6, p. 7 .

${ }^{15}$ PP I $884-85$ (c. 4279) LV. I, No. 22, p. I6.

${ }^{16}$ For the standard form, see FO $403 / 3$ I, enc. I in No. 88, p. 58.

17 These treaties were followed by a new Order in Council in $\mathrm{I} 885$ regulating extraterritorial jurisdiction: London Gazette, Io April I885, p. I6I7. For various drafts, see FO 84/I 659 .

${ }^{18}$ John E. Flint, Sir George Goldie and the Making of Nigeria (London, Oxford University Press, I960), p. 60. When Hewett signed treaties with these rulers, they were subject to the trading terms agreed by the rulers with the company: see Hertslet, Commercial Treaties, vol. I7, p. I 58 . For a list of the treaties and their form, see PP I899 (c. 9372) LXIII. 4I7, pp. I7-35.

19 Sir William M. N. Geary, Nigeria under British Rule (Routledge, London, 2013), pp. $93-95$. 
Hewett's mission began shortly after the conclusion of the Berlin Conference, whose General Act set out the formalities to be observed by the powers in respect of new occupations on the African coast. ${ }^{20}$ The act required the signatories to notify the other powers if they assumed a protectorate. ${ }^{2 \mathrm{I}}$ It was with a view to complying with this requirement that an announcement was made on 5 June 1885 , in the London Gazette, that the territories in the Niger districts between the Lagos colony and the western bank of the Rio del Rey were 'placed under the Protection of Her Majesty the Queen' by virtue of 'certain Treaties' concluded over the previous year and 'by other lawful means'. ${ }^{22}$ The notification did not purport to make any new claims, but merely to confirm an already existing situation. At the same time, plans were made to 'enable Great Britain to carry out the duty imposed on her by the Berlin Conference to enforce the freedom of navigation on the Niger', through an amended West African Order in Council and by granting a charter to the company - which would in I 886 become the Royal Niger Company. ${ }^{23}$ While Britain wanted to secure its interests in this region, it was not interested in incurring expenses; Britain was therefore happy to allow the Royal Niger Company to take on much of the financial responsibility. Under the charter, the company obtained broad powers to govern those areas in the Lower Niger region in which it had signed treaties, which it continued to exert until I 899 .

Although Britain proclaimed a protectorate in $\mathrm{I} 885$, it was not until I 89 I that steps were taken to increase effective control in the area. In I890, the government sent a special commissioner, Major Claude MacDonald, to the region to consider its future administration. Having recommended a 'strong Consular administration' with an executive with power to maintain order and 'assist in opening up the country', ${ }^{24}$ MacDonald was appointed the first Consul-General. He was given instructions to amend the treaties which had been signed

${ }^{20}$ For a discussion, see Johnston, Sovereignty and Protection, ch. 7.

${ }_{21}$ Article 34: PP I 884-85 (c. 436I) LV. I33, p. 3 I 2.

22 Joseph C. Anene, Southern Nigeria in Transition, I 885-1906: Theory and Practice in a Colonial Protectorate (Cambridge, Cambridge University Press, I966), p. 67.

23 See Pauncefote to Granville, ıo March I 885, FO 84/ı 879, f. 67; see further Flint, Sir George Goldie, pp. 74-87.

${ }^{24}$ Instructions to MacDonald, I7 January I889, FO 84/1940, f. I at f. 5; Anene, Southern Nigeria in Transition, pp. I2I, I30-I3I. 
with the local chiefs 'in order to consolidate the Protectorate and strengthen the foundation on which it rests', and to sign further treaties to bring all the territories under a uniform system of administration. He was also instructed to pave the way for direct British rule by developing legitimate trade, promoting civilization, inducing the Africans to relinquish their 'barbarous customs, and by gradually abolishing slavery'. ${ }^{25}$

\section{Jaja of Opobo}

In the years which followed the Berlin Conference, as Britain sought to increase her influence in this area, she came into conflict with three leaders who had signed Hewett's treaties. Their obstruction to the opening of their territory to British trade, and ultimately British rule, would lead to their deposition and removal from their territory. The first to be removed was Jaja, king of Opobo. ${ }^{26}$ Jaja, born about I 82 I, had progressed from being a domestic slave within the house of the king of Bonny to becoming a prosperous trader and ruler of Opobo. Jaja established himself in Opobo after going to war with the king of Bonny. Having brokered a peace treaty between Jaja and Bonny, the British entered into a treaty with Jaja in I 873, which acknowledged his status as king. Since the British wanted to keep European traders out of the area (given the high cost of protecting them), the treaty also stipulated that no European trading establishments would be permitted in Opobo and that the Opobo River would be closed to traders above a certain point. ${ }^{27}$

In the early I880s, Jaja's relations with the British began to deteriorate. When in I88I he claimed sovereignty over the Qua Eboe river and its people, Consul Hewett warned him off, stating that they

25 Salisbury to MacDonald, I 8 April I89I, FO 84/2 I Io f. I 4 at ff. I 5-I6. See also MacDonald's Report on the Administration of the Niger Coast Protectorate, I 6 August I 894, FO 403/200, enc. I in No. I23, pp. I99ff.

26 For Jaja's history, see Sylvanus Cookey, King Ja Ja of the Niger Delta: His Life and Times, I82I-I89I (New York, NOK, I974); and E. J. Alagoa, Jaja of Opobo: The Slave Who Became a King (London, Longman, I970). See further Paul MacDonald, Networks of Domination: The Social Foundations of Peripheral Conquest in International Politics (Oxford, Oxford University Press, 20I4), pp. I70-I75.

27 PP I888 (c. 5365 ) LXXIV. I49, No. 2, p. 3; No. 8, p. I4. 


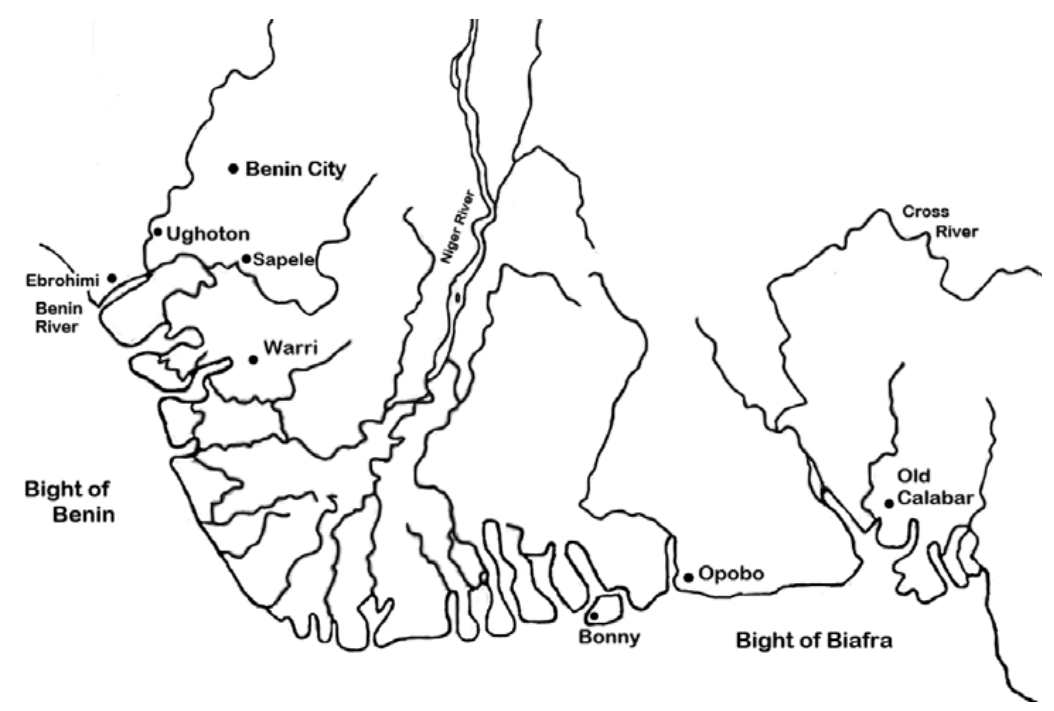

MAP 4 The Oil Rivers

were under British protection. ${ }^{28}$ Disagreements over Qua Eboe continued to the end of 1884 , when Jaja signed the standard-form treaty which Hewett had brought to Africa. ${ }^{29}$ In fact, it took time to persuade Jaja to agree. In July, Hewett was only able to induce him to sign a preliminary treaty - containing the first two clauses of the main treaty - since he 'found with Ja Ja that it would take too much time to explain and argue out all the clauses'. ${ }^{3 \circ}$ At the same time, he reassured Jaja that he would still govern the country if he signed the treaty, since 'the Queen does not want to take your country or your markets'. ${ }^{\text {I }}$ When eventually he did sign the treaty, Jaja struck out Article VI, which would have allowed for free trade in every part of his territories. ${ }^{32}$

In the meantime, a conflict was also brewing between Jaja and British merchants, who wanted to cut their costs by dropping the commissions paid to African traders. To secure this, they formed a cartel; but Jaja

${ }^{28}$ PP I 888 (c. 5365 ), No. 4, p. 4, enc. 4 in No. 4, p. 8. In fact, no treaty of protection had been signed with the people of Qua Eboe: $\mathrm{FO}_{403} / 86$, No. 8, p. I 2.

29 By the time Hewitt got to Jaja, he had already sent thirty-seven concluded treaties to London. $\mathrm{FO}_{403} / 33$, No. 28, p. 23.

30 Hewett to Granville, 30 July I 884 , FO 84/ı660, f. I78.

${ }^{31} \mathrm{PP}$ I 888 (c. 5365 ), enc. in No. I3, p. 29; FO 403/3 I, No. 88, p. 57.

32 PP I 888 (c. 5365 ), No. I 2, p. 27. 
induced one firm, Miller, Brother and Co. of Glasgow, to withdraw from the cartel in return for a large share of the trade. ${ }^{33}$ The remaining firms sought to undermine Jaja's position as a middleman by opening up the markets of the interior themselves, which they considered they had a right to do by virtue of Hewett's treaties. Since Jaja considered that the treaty he had signed did not require him to yield his markets to Europeans trading on 'my river', ${ }^{34}$ he maintained his control by turning back the white agents of the cartel members, and flogging their African ones. Faced with his obstruction, the cartel thought that the only way to make Jaja understand his duties under the treaty was 'to send a man-of-war here to settle the dispute for us'. ${ }^{35}$ This was a view shared by the newly arrived Vice-Consul, Harry Johnston, who felt that the most effective way to support commerce in the area would be 'the humiliation or banishment of Jaja'. ${ }^{36}$ The Foreign Office also considered that Jaja's behaviour might 'make the exercise of the British Protectorate difficult unless he is sharply dealt with'. They kept the Admiralty fully informed of developments, in case military assistance was needed. ${ }^{37}$

In March I886, having called Jaja and the merchants together to a palaver on board the Watchful, Hewett concluded that the merchants had a right to go up the river, since the British government had declared that 'they will allow no monopolies in trade in their countries'. He also found that Jaja had violated the 1873 treaty by enforcing commission payments, and imposed a fine for this alleged breach, which Jaja paid under protest. ${ }^{38}$ Although the Foreign Office supported Hewitt's actions, it concluded that he had erred in fining the king under the terms of the I 873 treaty, since that treaty had authorised Jaja to deny British traders the access to the interior markets which Hewett insisted they should have. ${ }^{39}$ The view of the Foreign Office was that Jaja had rendered the I 873 treaty nugatory by his acts, and that it had been superseded by the

33 PP I 888 (c. 5365 ), enc. 3 in No. I8, p. 3 I.

34 PP I 888 (c. 5365 ), No. I3, p. 28 ; No. I6, p. 30 ; enc. 5 in No. I8, p. 33.

35 PP I 888 (c. 5365 ), enc. 6 in No. I8, p. 33. ${ }^{36} \mathrm{FO}_{403} / 86$, No. 7, p. I I.

37 FO 403/86, No. 9, p. I3. Admiral Hunt-Grubbe was ready to remove Jaja to Ascension in case of need, though he felt that the king should first hear Hewett's advice: enc. I in No. II, p. I4.

38 PP I 888 (c. 5365 ), enc. in No. 24, p. 4I; No. 2I, p. 35 ; No. 22, p. 36.

39 Hewett had told the palaver that Europeans had the right to go upriver by virtue of the Berlin agreement; though he did not make this point in the record of the decision or his report to the Foreign Office. $\mathrm{FO}_{4} \mathrm{O}_{3} / 86$, enc. in No. I3, p. I7 at p. I 8. 
I 884 Protectorate Treaty. ${ }^{40}$ On I6 June I 886 , Foreign Secretary Rosebery duly informed Jaja that the 1873 treaty had been superseded, and told him that the Queen's aim in assuming the 'Protectorate of territories on the Gulf of Guinea', was '[t]he promotion of the welfare of the natives ... by insuring the peaceful development of trade'. No chief would be allowed to obstruct this policy to benefit himself. $^{4 \mathrm{I}}$ This was to ignore the particular provisions of Jaja's treaty, and in early 1887 , Jaja reminded Rosebery's successor at the Foreign Office, Salisbury, of the promise that the Queen did not want to take his country or his markets. ${ }^{42} \mathrm{He}$ also sent his sons and some chiefs to London to put his case directly to the Foreign Office.

A new dispute flared up in the middle of I 887 over access to the market at Ohambele, the main Ibo market. When traders from the cartel sent steamers upstream, they found the locals in terror of speaking to them, having been threatened by Jaja. ${ }^{43}$ Jaja had also deposed the local king and replaced him with one friendly to himself, Ekike Notsho. ${ }^{44}$ In response, the Acting Consul, Johnston, was sent to Opobo in July, where he called a palaver with the merchants and Jaja. At the meeting Jaja admitted that - 'in spite of the Berlin Conference, the Protectorate Treaty, and divers admonitions from Foreign Secretaries and Consuls' (as Johnston put it ${ }^{45}$ - he had made the people of the interior take solemn oaths 'chop ju-ju' - that they would deal only with him: effectively excluding the British traders. Johnston informed the king that he would consider the matter closed if he agreed to punish any of his subjects who obstructed trade, and if he sent chiefs with Johnston into the interior to lift the oath. ${ }^{46}$ Otherwise a gunboat would be sent. Although Jaja agreed to the conditions at a second palaver some days later, he protested that his agreement had been exacted under

${ }^{\circ} \mathrm{FO} 403 / 86$, No. 20, p. 24; PP I 888 (c. 5365 ), No. 25, p. 42.

${ }^{4}$ PP I 888 (c. 5365 ), No. 25, p. 42. Although the Foreign Office realised that the fine should have been remitted (as void), Jaja was told that it would be held over for a year, subject to his behaving well.

42 PP I 888 (c. 5365 ) No. 27, p. 43; No. 33, p. 47.

43 FO $403 / 73$, No. 8 I, p. 57 ; enc. I in No. I09, p. 85.

44 FO $403 / 73$, No. 99 with enclosures, p. 78.

45 PP I 888 (c. 5365 ), enc. 2 in No. 52, p. 65 at p. $66 . \quad{ }^{46}$ PP I 888 (c. 5365 ), No. 39, p. 50. 
compulsion, and stated that he wanted to let the matter rest until his envoys had returned from London. ${ }^{47}$

The day after the second palaver, Johnston went to Ohambele with three of Jaja's chiefs. Although Jaja's men were not entirely cooperative, the ju-ju was broken, and the Eboe agreed to enter a treaty. ${ }^{48}$ However, when he returned some days later, Johnston was informed by Ekike Notsho - who claimed to speak for the Eboe - that the treaty would not be signed, and that the whites would not be allowed to trade rubber or palm oil. The whole question of free trade now seemed to Johnston to rest on the outcome of the dispute over Ohambele, since 'from Benin to Old Calabar, all the native Chiefs are watching with interest the long struggle between the traders and the Trader-King of Opobo'. ${ }^{49} \mathrm{He}$ now prohibited any trade between Jaja and British subjects. ${ }^{50}$

Johnston's belief in the need for tough action was echoed by Hewett, who was in London on a period of leave. He told Salisbury that 'this upstart of a King' needed to be 'dealt with in a severe and exemplary manner', by being deposed and deported to St Helena or Ascension. ${ }^{5 \text { I }}$ However, Salisbury was more cautious, seeking more information about exactly which promises Jaja had broken. ${ }^{52} \mathrm{He}$ was also reminded by Jaja's envoys, who had arrived in London, that Jaja's rights over trade (recognised in I 873) had been purposely preserved in I 884, and that he would not have signed Hewett's treaty had Article VI not been struck out. ${ }^{53}$ Reviewing the case, Salisbury concluded that Jaja appeared to be de facto suzerain of Ohambele, so that it was perfectly within his power to prohibit European trade. He saw no infringement of the treaty of 1873 which would justify intervention, and considered that Rosebery's letter of June I 886 had no authority. In

47 I 888 (c. 5365), enc. 5 in No. 46, p. 6I; No. 46, p. 59. He was advised by A. H. Turnbull, the agent of Miller, Brother \& Co., to sign under protest and to complain to the Foreign Office: FO $403 / 73$, enc. in No. I 56 , p. I 8.

${ }^{48}$ PP I888 (c. 5365 ), No. 45 , p. $55 . \quad{ }^{49}$ PP I 888 (c. 5365 ), No. 59, p. 70.

${ }^{5} \mathrm{PP}$ I 888 (c. 5365 ), enc. I in No. 59, p. 72 . He also threatened the agent of Miller, Brother \& Co. that if he continued to trade, he would himself be deported. Johnston's actions led to protests from the company. See $\mathrm{FO}_{403} / 73$, No. I03, p. 8 \% №. I I 2 , p. 87 ; No. 123 , p. 98 ; $\mathrm{FO}_{403} / 86$, enc. 4 in No. 80 , p. $7 \mathrm{I}$; enc. in No. 73 , p. 62 at p. 65 ; encs. in No. IO3, p. 84.

${ }_{51} \mathrm{FO}_{403} / 73$, No. 106, p. $82 . \quad{ }^{52} \mathrm{FO}_{403 / 73}$, No. I06, p. 83 at p. 84.

${ }^{53} \mathrm{FO} 403 / 86$, No. 26, p. 29. 
his view, there was no cause of war against Jaja 'according to any sort of rules of international right'. ${ }^{54}$ Salisbury came to the conclusion that an investigation was needed into the exact nature of Jaja's rights, both under the treaty of 1873 and with respect to Ohambele. If he had imposed an illegal blockade, then he could be punished; if not, there would have to be negotiations about the future. ${ }^{55}$ Consequently, when Jaja's envoys, accompanied by a representative from Miller, Brother and Co., had a meeting with Sir James Fergusson, the undersecretary of state, on 13 September, they were informed that an investigation would take place, conducted by a naval delegation. ${ }^{56}$

London's caution was overtaken by events on the ground. When Johnston attempted to go upriver at the start of September, to help establish trading stations, he found the Azumena creek blocked by hostile Africans who appeared to be acting on Jaja's orders. ${ }^{57}$ Fearing what Jaja's future plans might be if his envoys did not succeed, ${ }^{58}$ Johnston sent a telegram to London asking permission to remove Jaja to the Gold Coast. ${ }^{59}$ A mix-up seemed to give him the answer he wanted. Ten minutes before his telegram arrived at the Foreign Office, a telegram was sent to him, approving his action with regard to Jaja. ${ }^{60}$ This telegram referred to earlier correspondence from Johnston, but he read it as a response to the telegram he had just sent, giving him the green light to detain Jaja. He now proceeded to execute his plan. He summoned Jaja to a meeting on I9 September, reassuring the king that everything would be done in a friendly and temperate spirit, without the use of force. ${ }^{6 \mathrm{I}}$ However, when Jaja came to the meeting, he was told that he would be taken to Accra for an inquiry into the charges against him. If he was found guilty, he would be exiled, if not he would be restored to his position. Jaja was also told that if he did not come voluntarily, this would be taken as an admission of guilt, and any resistance offered would be mercilessly crushed. ${ }^{62}$ Jaja had no option but to accept, and within the hour, he was

\footnotetext{
54 FO $403 / 73$, No. II 8, p. 9I. $\quad 55$ FO 403/73, No. I3 I, p. IO2.

${ }^{56}$ PP I 888 (c. 5365 ), No. 53, p. 68.57 PP I 888 (c. 5365 ), No. 63, p. 78.

$5^{8}$ As he wrote to Captain Hand, 'He may either sell his country to France ... Or he may sack the factories, kill the white men, and retire into the inaccessible interior with his plunder': $\mathrm{FO}_{403} / 86$, enc. 7 in No. I I 2, p. 96 at p. 97.

59 PP I 888 (c. 5365 ), No. 43, p. 54. ${ }^{60}$ FO $403 / 86$, No. 37, p. 37.

${ }_{61} \mathrm{FO}_{403} / 86$, enc. 3 in No. I 24, p. I04; PP I 888 (c. 5365 ), No. 67, p. 80.

62 PP I 888 (c. 5365), enc. I in No. 67, p. 83.
} 
on his way to Accra. Johnston then proclaimed free trade, and ordered the arrest of Ekike Notsho.

The Foreign Office was alarmed at this turn of events. It could not disown the actions of its consul, but neither could it go back on the promise of an investigation, which Salisbury now began to regret. The prospect of having to pass an ordinance to authorise Jaja's detention also worried Salisbury, who noted, 'Do not let us have another Zebehr' ${ }^{63}$ The authorities initially hoped that Jaja could be persuaded to remain in Accra voluntarily, but Governor White was compelled within two days to introduce the required ordinance since Jaja had broken his 'parole' by 'listening to ill-advised counsel' (the lawyer Edward Bannerman), and by 'telegraphing to friends in England with a view to obtaining his release'. ${ }^{64}$ Provision was also made to hold his envoys, whom Johnston wanted to be detained on their return either as hostages (in the case of his sons) to secure Jaja's good behaviour, or (in the case of the chiefs Cookey Gam and Shu Peterside) to keep their followers in Opobo quiet. ${ }^{65}$

Meanwhile plans were made for the investigation which had been promised. In order to ensure that it would be perceived to be impartial, Rear-Admiral Walter Hunt-Grubbe, Commander-in-chief on the Cape of Good Hope and West Coast of Africa station, was appointed to conduct it. ${ }^{66}$ To allow Jaja to attend (and be represented by Bannerman), HuntGrubbe decided to hold the inquiry at Accra, rather than Opobo. ${ }^{67}$ According to his instructions from the Foreign Office, which appeared to accept Jaja's view of the I 884 treaty, Hunt-Grubbe was to examine whether Jaja had merely exercised his right to control trade within his own jurisdiction, or whether he had barred 'the trade to the inland districts beyond his own jurisdiction, such as Ohombela is alleged to be'. Hunt-Grubbe would be 'at liberty to inflict whatever punishment he may deem right' if Jaja had blocked the highway; but if he had only restricted trade within his own areas, there would be negotiations to obtain favourable terms for British traders. ${ }^{68}$

63 FO $403 / 86$, No. 50, at p. 49.

${ }^{6} \mathrm{FO}{ }_{403} / 73$, enc. 2 in No. $238 \mathrm{E}$, p. I89; enc. 4 in No. $238 \mathrm{C}$, p. I90A (Opobo Political Prisoners Detention Ordinance No. I6 of I887). See also White to Holland, 5 October I $887, \mathrm{CO}_{96 / 1} 83 / 22$ I 36.

65 Johnston to White, 3 October I 887 , CO 96/I83/22 I36. He had sent a telegram to White on 18 September, asking him to detain the envoys: CO 96/ I 83/I 8885 .

66 PP I 888 (c. 5635 ), enc. in No. 60, p. 74. ${ }^{67}$ FO 403/86, No. I37, p. I I4.

68 Foreign Office to Admiralty, 27 September I 887, PP I888 (c. 5635 ), No. 5 I, p. 63. 
In the event, Hunt-Grubbe approached the inquiry with a broader brush. When the investigation began on 29 November, he set out three questions to be investigated. First, had Jaja barred trade to places beyond his jurisdiction, such as Ohambele was said to be? Second, had he at any time blocked the highway? Third, had he 'loyally endeavoured' to carry out the I 884 treaty? ${ }^{69}$ Jaja denied blocking the creek, breaking the treaty of $\mathrm{I} 884$, or making 'ju-ju' since that date. He also pointed out that the treaty had said nothing about opening new markets to the Europeans. ${ }^{70}$ The main evidence against him came from Johnston, who was hardly an independent witness. Besides blaming him for the event on the Azumena creek, ${ }^{7 \mathrm{I}}$ Johnston complained that Jaja had breached Article V of the treaty, under which he agreed to act on the advice of the consular representative, by sending a deputation to London without first communicating with him. The Rear-Admiral clearly found the evidence against Jaja more comprehensible than that in his favour, for he later reported 'I found it quite impossible to take minutes as is usual at a Court of Inquiry, the vernacular of the natives being so peculiar. ${ }^{72} \mathrm{He}$ gave his decision on I December. Jaja's central argument, that he had preserved rights under the I 884 treaty which the British were seeking to infringe, was not addressed in Hunt-Grubbe's finding, though he did accept that it had not been proven that Jaja had barred the trade to Ohambele. As for the obstruction on the Azumena creek, Hunt-Grubbe found that Jaja's men were present, and 'though they took no active part in obstructing the Consul, they were the reverse of friendly'. This was sufficient in his view to prove the second charge. As for the third, the charge of failing loyally to carry out the provisions of the treaty was proven not only by Jaja's reluctance to break the 'ju-ju', but also by his sending a mission to England without Johnston's knowledge or sanction. The real grounds of the decision were to be found in HuntGrubbe's concluding remark: 'Opobo requires rest to enable proper and free trade to be developed. Your presence in the river would be fatal to peace and progress.' Hunt-Grubbe's recommended that Jaja be exiled for at least five years, with the king being allowed to choose between Ascension, St Helena, the Cape Colony or the West Indies. ${ }^{73}$

\footnotetext{
$69 \mathrm{FO}_{403} / 74$, enc. in No. I, p. $2 . \quad{ }^{70} \mathrm{FO}_{403} / 74$, enc. 3 in No. 6, p. 7.

${ }^{71} \mathrm{FO} 403 / 74$, enc. 6 in No. 6, p. $9 . \quad{ }^{72}$ FO $403 / 74$, enc. 7 in No. 6, p. II.

$73 \mathrm{FO}_{403 / 74}$, enc. in No. I, p. 2.
} 
It did not take long for Miller, Brother and Co. to complain about the nature of the proceedings,${ }^{74}$ nor for the matter to be raised by the Irish Nationalist MP William Redmond in parliament. ${ }^{75}$ Under sustained pressure from MPs, the government agreed to publish a Blue Book, though there were concerns over how much material to include in it. Looking through Hunt-Grubbe's précis of evidence, the Foreign Office's legal adviser, W. E. Davidson, noted that the only point established by independent evidence at the hearing was that the king had made 'ju-ju' since I 884. It was clear to Davidson that the proceedings fell far short of the standards expected of English criminal law, and that there would be plenty for hostile critics to attack if it were published. ${ }^{76}$ On his advice, the précis of evidence was left out of the Blue Book. The published version did, however, contain one potential hostage to fortune, which was spotted by the Foreign Office's lawyers: a careful reading of the telegrams published in it would reveal that Johnston had detained and removed Jaja on a misapprehension that he had authority to do so. The fact that he had no authority would mean that Jaja's rendition from Opobo to Accra had been illegal, which might open the way for legal proceedings on his behalf. On advice from the Law Officers that the transit of a detainee between colonies could be regarded as an act of state ${ }^{77}$ - removing his right of action - but only if it was properly ratified, the Foreign Office formally notified Johnston on 7 April 1888 that it was ratifying his actions in removing Jaja ${ }^{78}$ In this way, the Foreign Office sought to ensure that its treatment of Jaja was, at least formally, legally watertight.

In May I 888, Jaja sailed for St Vincent, where an ordinance was passed to authorise his detention. When Jaja's health began to deteriorate, Salisbury worried that his death in exile 'would be very extreme embarrassment. It would induce a close inquiry into the circumstances of his deportation which cannot be defended according to European notions of good faith. ${ }^{79}$ Eventually, the Foreign Office decided to move him to Barbados, but when his health continued to decline there, the decision was taken that he should be

$74 \mathrm{FO}_{403} / 74$, No. 4, p. 4; No. I9, p. 2 I; No. 28, p. 26.

75 Parl. Debs., 3rd ser., vol. 323, col. 24 (2 March I 888). $\quad{ }^{76}$ FO 403/74, No. 78, p. 65 .

$77 \mathrm{FO}_{403} / 74$, No. 62, p. 50, referring to Buron v. Denman (I848) 2 Ex. I66.

${ }^{78} \mathrm{FO} 403 / 74$, Nos. 73-74, p. 6I.

79 Salisbury minute I7 June I889, FO 84/I940, quoted in Cookey, King Ja Ja, p. I 54. 
sent home. But Jaja never made it: sent first to Tenerife, to await MacDonald's arrival, he died on the island in July г 89 I.

Jaja was the first of a number of rulers in the Niger delta who would be deposed and removed by the British as they asserted their authority in the region in the aftermath of the Berlin Conference. At a turning point in the imperial project, the changing notion of protectorates placed Jaja in an uncomfortably ambiguous position, halfway between sovereign and subject. Jaja regarded himself as an independent sovereign, whose relationship with Britain was defined by a treaty which preserved his rights over trade in areas which included Ohambele. By contrast, his adversaries - including Johnston and Hunt-Grubbe - regarded the king as bound to act on the advice of the British consul, and disregarded the reservation of his rights. In the view of the consular officials, Britain's right to trade derived from the broader agreement at Berlin, of which Jaja was not a part. In principle, the dispute between Jaja and the British over his right to control trade was a question of international law, for Jaja was not a subject and had violated no domestic law. In the end, the British came up with a Napoleonic solution to the problem of how to deal with him exile by ad hominem legislation. However, to justify this, they conducted a non-judicial investigation into his conduct, as they had with Abdullah of Perak. In Abdullah's case, the justification for this was that the Sultan was suspected of criminal conduct for which he could not otherwise be prosecuted; but in Jaja's, his offence was simply that he had obstructed British trade ambitions. Here, the rule of law gave way to Realpolitik and to the economic interest of British merchants. If Jaja had the better of the legal arguments, they counted for little in the eyes of British officials who justified their actions in terms of economic advantage, and who were able to impose their will thanks to their military power. As had happened elsewhere in West Africa, the local officials were able to drive the policy, so that the Foreign Office was ultimately prepared to put aside such legal doubts as they had. With relatively weak support in England, Jaja was unable to make his voice heard. In this context, the legal instruments used to authorise the king's removal were formalities, which gave the stamp of legality to economic self-interest. 


\section{Nana Olomu}

In I 896, nine years after Jaja's removal to the Gold Coast, another ruler from the Niger delta, Nana Olomu, was removed to Christiansborg Castle, where he was detained under an ordinance passed for the purpose. However, the legal route taken by the British in Nana's case was markedly different from that taken in Jaja's. By this stage, earlier British ideas that the jurisdiction of the protecting power over Africans depended on the express terms of a treaty had given way to the view that 'the existence of a protectorate in an uncivilised country imports the right to assume whatever jurisdiction over all persons may be needed for its effectual exercise'. ${ }^{\circ \circ}$ At a time when the protectorate had been established in the Oil Rivers with a structure of administration and governance, Nana would be treated much more like a recalcitrant subject than an autonomous ruler, in the end facing trial in a consular court. In his case, a more elaborate version of 'lawfare' was used to remove another obstructive ruler.

Nana was the most powerful Itsekiri chief. ${ }^{8 \mathrm{I}}$ The Itsekiri were middlemen in the trade in palm oil, buying oil from the Urhobo further inland, and selling it to European merchants. Much of the Itsekiri population had migrated in the middle of the nineteenth century from Warri to the lower Benin River, where two branches, or Houses, established themselves on opposite banks of the river. ${ }^{82}$ Nana's father Olomu, who by the I 860 s was the wealthiest trader on the river, was a member of the house of the Ologbotsere (on the north bank). Following the pattern of richer Itsekiri, he established his own village at Ebrohimi on the Benin River, from where he was able to establish his supremacy over trade on the river, monopolising it through his large fleet of war canoes. In I879, Olomu was elected Governor of the River, a position which had been created on the initiative of Consul Beecroft, after a succession crisis in the middle of

${ }^{80}$ Law Officers' Opinion (relating to the Gold Coast), I4 February I 895, CO 88 5/I4, No. 78 .

${ }^{81}$ See Obaro Ikime, Merchant Prince of the Niger Delta: The Rise and Fall of Nana Olomu, Last Governor of the Benin River (London, Heinemann, I968); and Anene, Southern Nigeria in Transition, pp. I49-I6I.

${ }^{82}$ See P. C. Lloyd, 'The Itsekiri in the Nineteenth Century: An Outline Social History', Journal of African History, vol. 4:2 (I963), pp. 207-23 I; and A. F. C. Ryder, Benin and the Europeans, I485-I897 (London, Longmans I969), pp. $243 \mathrm{ff}$. 
the century left the Itsekiri crown in abeyance. ${ }^{83}$ The task of the Governor was to maintain peaceful trade on the river, and - at least in the eyes of the Itsekiri - to protect their trading interests.

When Olomu died in 1883 , control of his trade passed to his son Nana. One year later, Consul Hewett asked the Itsekiri elders to elect a new Governor of the River, and Nana was chosen. In the same year, he signed Hewett's protection treaty, though, like Jaja, he did not agree to the clause opening up the river to free trade. ${ }^{84}$ In 1885 , he was presented with a staff of office 'sent by Her Majesty's Government, under whose protection Nana and his people had placed themselves', so that the other chiefs present could acknowledge their allegiance to him and 'know that the power of Her Majesty's Government supports you in your authority'. ${ }^{85}$ The actions of the Foreign Office in purporting to confer authority on Nana were in part explained by potential jurisdictional conflicts it had in this area with other elements of the British imperial state, namely the Royal Niger Company and the Colonial Office: in particular, it wanted to ensure that Nana's authority to make treaties on behalf of other chiefs was recognised, since this would override any protection treaties they might have made with the Royal Niger Company. ${ }^{86}$ At the same time, the Foreign Office's jurisdiction over Nana was put in question by the proclamation made in February I 886 by Governor W. Brandford Griffith under which the north bank of the Benin River - where Ebrohimi lay - was to be added to the colony of Lagos. ${ }^{87}$ As for Nana, he did not himself think that he owed his position to any British appointment.

${ }^{83}$ Lloyd, 'The Itsekiri in the Nineteenth Century', p. 2 I6, citing Beecroft to Palmerston, I9 April I 85 I, FO 84/8 58 , f. I 62 at f. I9 Iff.

${ }^{84}$ Nana and Chanomi signed the treaty, but added the words 'except as regards Articles VI and VII which are to be left for negotiation on a future occasion'. Hewett to Granville, 30 July i 884 , FO 84/ז660, f. I78.

${ }_{5}$ Presenting it, Vice-Consul Blair added, 'I look to you as the executive power through which the decrees of Her Majesty's Consular Court are to be exercised and enforced': FO 84/2109, f. I05v.; FO 2/64, f. 360.

${ }^{86}$ Hewett to Granville, 25 August I 884, FO 84/I660, f. 204. MacDonald concluded that Nana had not made out his claim to jurisdiction over Goolah and Borutu, and that they had made valid treaties with the company: FO 84/2 I09, f. I Iov.

${ }^{87}$ Nana was not informed about this and 'considered himself under consular jurisdiction and not as belonging to the Colony of Lagos'. FO 84/2109, ff. I05-I06. 
From the British point of view, Nana's position as Governor became redundant in I89I with the establishment of the Oil Rivers Protectorate. When MacDonald toured the rivers in the summer to explain the operation of the new system, Nana signed a declaration consenting to the new customs duties to be imposed; though he also took the opportunity to make an impassioned complaint about the way he had been treated by Acting Consul George Annesley, when he purported to depose him from the position of Governor in I 890. The British were now keen to open up trade in the interior and to by-pass middlemen such as Nana, who (as MacDonald put it) was 'already sufficiently powerful, and threatens to become a second Ja-Ja'. ${ }^{88}$ Despite complaints of Nana's obstruction of trade, ${ }^{89}$ the new ViceConsul for the Benin River, Capt. H. L. Gallwey, remained optimistic that, once law and order had been put on a sound footing, white traders would have direct access to the markets of the Urhobo. He even assured the Urhobo, who were constantly at war with the Itsekiri and complained about only being able to deal with Nana, 'that trade was free now' and that anyone obstructing it 'would be severely punished'. ${ }^{\circ}$ However, Nana continued to exert his authority over the African trade and to restrict access to these markets. This prompted Gallwey in June 1892 to accuse him of 'playing a very dangerous game' and to threaten gun boats. ${ }^{9 \mathrm{I}}$ In April I894, MacDonald again warned Nana not to interfere with freedom of trade, telling him that 'the Government of the Queen is established here, you are no longer chief of the Jakri [Itsekiri] people'. ${ }^{2}$

When MacDonald went on leave in the summer of 1894 , his replacement, Ralph Moor, began to take some more decisive steps to deal with this obstructive chief. ${ }^{93}$ After hearing that Nana's people were 'generally terrorizing the locality', ${ }^{94}$ he went to the Benin River and summoned Nana to discuss some matters of 'vital importance'. When Nana sent an excuse for not attending, Moor wrote back that he

${ }^{88} \mathrm{FO}_{403} /$ I7I, No. 6I, p. 39 at p. 42; cf. Nana to Salisbury, I 4 December I 890, FO $2 /$ 64, f. 364 .

89 For example, Hewett to Nana, 24 February I 887 , FO 2/64, f. 362.

$90 \mathrm{FO} 403 / \mathrm{I} 7 \mathrm{I}$, enc. I in No. II 8, pp. 8I-82.

${ }^{91}$ Gallwey to Nana, 2I June I892, FO 2/64, f. 366.

92 MacDonald to Nana, 5 April I 894, FO 2/64, f. 373.

93 Anene, Southern Nigeria in Transition, pp. I 54-I $55 . \quad 94$ FO 403/200, No. I 24, p. 240. 
wanted to discuss both Nana's interference with the trade and the fact that his headman Ologuy had seized several Urhobo. Nana was given fourteen days to return the captives and to replace Ologuy. He was warned that if he did not comply, the Ethiope river would be closed to his people. ${ }^{95}$ In his reply, Nana denied any desire to interfere with the Urhobo traders, and explained that the men taken captive were being held as security for a debt of the Eku Urhobos. ${ }^{96}$ This did not satisfy Moor. In his view, in seizing Urhobo slaves as security for his debt, Nana had taken the law into his own hands, when he should have referred the matter to the consular court. Moor told Nana to hand over the captives to this court, and to produce Ologuy to give evidence. Until this was done, the Ethiope river would be closed to his people. ${ }^{97}$ Having heard that Nana was threatening to attack two friendly chiefs, Dore and Dudu, he further arranged for the Alecto to be sent to the river..$^{8}$

Summoning him to another meeting in August, Moor promised Nana that he would not be molested in any way if he attended, but warned that, if matters were not settled in a friendly manner, 'other measures must be taken'. ${ }^{99}$ However, Nana remained convinced that he would suffer the same fate as Jaja if he went. He therefore sent a representative to this meeting, where the other Itsekiri chiefs entered a new treaty which included the free trade provisions. Nana was now informed that his people were forbidden to use any waterways in the Benin or Warri districts, and was ordered to remove a gate which he had placed on the creek leading to Ebrohimi, in violation of government orders that all waterways in the district were to be free for all traders. ${ }^{\text {I०० }}$ Although Moor gave him one last chance to come and sign the same treaty as the other chiefs, Nana remained convinced that the consul's aims were not peaceful. 'Please try your best and leave me, alone, Consul General', he wrote, 'I afraided the wars, of Government, no blackmens fitted to do anything against the Government, except the Lord God.' ${ }^{\text {го }}$ By then, the Alecto had

\footnotetext{
95 Moor to Nana, 25 June I 894, FO 2/64, f. 378.

96 Nana to Moor, 25 June I 894, FO 2/64, f. 380.

97 Moor to Nana, 20 July I 894, FO 2/64, f. 382.

$9^{8} \mathrm{FO} 403 / 200$, No. I 24, p. 240.

99 Moor to Nana, 3 I July I 894, FO 2/64, f. 388.

Ioo Moor to Nana, 2 August I 894, FO 2/64, f. 392.

ror Nana to Moor, 4 August I 894, FO 2/64, f. 393.
} 
already destroyed the barrier which Moor had objected to. During this operation, there was an exchange of gunfire with the Africans, which in Moor's view 'materially changed' matters: and he now ordered a blockade of Ebrohimi, to force Nana's submission. ${ }^{\text {IO2 }}$

Moor also set about disciplining those chiefs who supported Nana. After an Idzo chief - whose followers had attacked a neighbouring village - failed to respond to a summons from Moor (claiming he had referred the matter to Nana), Moor ordered the Alecto to burn down his village, 'exercising a form of lex talionis as punishment'. This was intended to convey the message that those who ignored British orders, on the assumption that Nana's was the only government, would face serious consequences. ${ }^{\text {I03 }}$ Nana's response was to hoist a white flag at the mouth of the creek leading to Ebrohemi and to place a notice there stating that he wanted peace. However, he still refused to meet Moor. Furthermore, his people still appeared to be attacking other villages and canoes. Moor now concluded that it was useless to continue to negotiate, and that a second gunboat would be needed. ${ }^{\mathrm{I}}{ }^{4}$

The crisis deepened when, on the morning of 24 August, an armoured steam-cutter, which had been sent up the Brohemie creek to reconnoitre for obstacles in the way of an attack on the town, was fired on, killing two men and severely injuring three. ${ }^{\text {105 }}$ Five days later, a large force was sent to open up a route to take the town by land. Faced with a very difficult terrain and unexpectedly strong defences erected by Nana, the decision was taken to blockade and shell the town in order to force Nana's surrender. ${ }^{\mathrm{I}}{ }^{\circ}$ When Nana sent messages seeking peace, he was told that the British would only accept his unconditional surrender, whereupon his life would be spared. ${ }^{107}$ Ebrohemi was finally captured on 25 September, but during the attack on the town Nana and many of his followers escaped. ${ }^{108}$ On the same day, Moor issued a proclamation declaring Nana an outlaw until such time as he surrendered to stand trial for

\footnotetext{
${ }^{\text {I02 }}$ Moor to Foreign Office, 6 August I 894, FO 403/200, p. 24 O.

${ }_{103} \mathrm{FO}_{403} / 200$, No. I 25, p. 242.

${ }^{104} \mathrm{FO} 403 / 200$, No. I 30 , p. $250 \mathrm{C}$; FO $403 / 200$, enc. 3 in No. I $43^{*}$, p. 270.

${ }_{105} \mathrm{FO} 403 / 200$, No. I43, p. 264. ${ }^{106} \mathrm{FO}_{403} / 200$, No. I43, p. 264 at p. 267.

${ }^{107}$ FO $403 / 200$, enc. in No. I6I, p. 286; enc. 2 in No. I72*, p. 300.

${ }^{108} \mathrm{FO}_{403} / 200$, No. I77, p. 302.
} 
levying war against the government of the Oil Rivers Protectorate. All his property was declared forfeited to the government. ${ }^{\text {109 }}$

Besides putting pressure on friendly chiefs to secure Nana's capture, ${ }^{\text {IO }}$ Moor contacted the Governor of Lagos, Sir Gilbert Carter, for assistance, should he go to Lagos. ${ }^{\text {II }}$ However, the colonial Governor was more concerned with ensuring that legal formalities were complied with than the acting Consul-General. Carter told Moor that Nana could only be arrested - under the provisions of the Fugitive Offenders Act I88I - if an appropriate warrant were issued. ${ }^{\text {II2 }}$ Indeed, when Nana surrendered voluntarily to Carter on 30 October, the Governor, who was aware that he had no legal authority to detain the chief, told him that he would be left at liberty as long as he made no attempt to escape. ${ }^{\text {II } 3} \mathrm{He}$ planned to hand over Nana to MacDonald, on his way back to the Oil Rivers Protectorate, provided that an appropriate warrant was issued. However, when MacDonald presented the warrant (which he had been forced to obtain by a detour to Forcados), Carter - perhaps influenced by the extensive discussions of the case which had taken place in Lagos - raised a further objection. He now asserted that, being on the right bank of the Benin River, Ebrohimi was within the colony of Lagos. This meant not only that Nana could not be handed over, but that he might even have a cause of action against the protectorate government. ${ }^{\text {II } 4}$ In the end, the dispute over jurisdiction - which was settled by a search through official correspondence in MacDonald's favour - became moot when Nana agreed to return voluntarily to the protectorate. ${ }^{\text {II } 5}$

In contrast to the naval investigation which looked into Jaja's conduct, Nana was to be put on trial. However, the trial turned out to be far from a model of the rule of law. Nana requested a trial at Lagos, where he had already consulted lawyers, but MacDonald opposed this, since he distrusted the verdicts of the mixed juries of

\footnotetext{
${ }_{109} \mathrm{FO}_{403} / 200$, inc. 4 in No. I77, p. 3 IO.

I ${ }^{\circ}$ FO $403 / 200$, No. 2 I 5, p. 35 I; No. 2 I 6, p. 35 I at p. 353.

II FO $403 / 200$, enc. 2 in No. 20I, p. 345.

I 2 He also pointed out that there were no powers for the government of Lagos to seize any of his assets held there. FO $403 / 200$, enc. 4 in No. 201, p. 346.

${ }^{\mathrm{II}} 3 \mathrm{FO}_{403} / 200$, enc. I in No. 2IO, p. 344. II4 FO 403/200, No. 2I6, p. 35 I.

II 5 FO 403/200, No. 2I6, p. 35 I; enc. in No. 2I 8 , p. 355.
} 
Europeans and Africans found there. ${ }^{\mathrm{II} 6}$ Instead, the trial, which began on 30 November, took place in the consular court at Old Calabar, under the provisions of the Africa Order in Council of I 893 ${ }^{1{ }^{117}}$ It was presided over by MacDonald himself - a career soldier with no legal training, and sitting without assessors - in a court which heard no legal argument, and in which neither side was represented by lawyers. Nana was to be held to account both for his armed resistance to the British military and for his political resistance to the opening up of the creeks to free trade. The first charge against him was that he had levied war against Her Majesty's Government, and endeavoured with arms 'to avoid carrying out the terms' of the treaty entered into in July I 884 (which under section I 6 of the Order in Council was to have effect as part of the law to be enforced). The second charge accused him of acting in opposition to British Consular officers in the execution of their duties, and in not taking their advice in matters relating to peace, order and good government 'and the general progress of civilization'. A third count charged him with breaches of the peace, and a fourth with incitement to breach of the peace.

The legal basis of these charges was not very clear, for the charge sheet only made three marginal references to legal provisions. Next to the charge of levying war, reference was made to section 48 of the Order in Council, which stipulated that 'any British subject' who levied war or joined in rebellion 'against any King, Chief, tribe or power' without Her Majesty's authority was liable to be imprisoned for two years, with or without a $£_{\mathrm{I}, \mathrm{O}}$ fine; the conviction also rendering the offender liable to deportation. Given that Nana was charged with levying war against the British Government - rather than any other local power - it was not quite clear why this section was relevant, particularly since the Order in Council explicitly provided that anything which constituted treason, felony or misdemeanour in England was also a punishable offence in the protectorate. In either event, the question was begged whether Nana was a 'subject' who could be amenable to such a charge. Furthermore, the charges

${ }^{\text {II } 6}$ FO $403 / 200$, No. 216, p. 35 I.

${ }^{117}$ Passed under the 1890 Foreign Jurisdiction Act, this extended the Africa Order in Council of I 889: see Francis E. Hodges, Consular Jurisdiction in Her Majesty's Protectorate of the Niger Coast (London, Stevens \& Sons, I 895). The Foreign Office authorised the creation of consular courts for various districts in the protectorate in July i 891: FO 403/I7I, No. 38, p. 26. 
relating to breaches of the peace made reference to section 102 of the Order rather than to any English offence. However, this section was not concerned with offences, but with the punishment of deportation. It stated that a person convicted of any offence could be required to give security for future good behaviour, and could - in default of such security - be deported. It also provided that anyone suspected of being about to commit a breach of the peace might be ordered to give security, or (in default thereof) be deported. The fact that it was mentioned in the margin of the charge sheet, in relation to the accusation of breaches of the peace, suggests a very hurried reading of the Order in Council by someone whose grasp of legal technicalities was very limited. ${ }^{\text {II } 8}$

Seven witnesses testified against Nana: the Consular Agent R. F. Locke, Moor and five African witnesses. Much of the evidence of the white administrators described the events since March, during which time Nana had stopped trade and seized slaves, and defied orders to attend meetings. Drawing heavily on correspondence seized from Nana's canoe, Moor painted a picture of a chief who owed his position to British patronage, and who persistently defied demands to allow free trade. ${ }^{\text {II } 9}$ Nana's accusers considered that he was bound by his treaty obligations to allow free trade: and indeed, the copy of his treaty, authenticated by MacDonald on the day that the trial commenced, included Article VI which guaranteed it. ${ }^{\text {I20 }}$ Although Nana had struck out this provision, unlike Jaja he did not at his hearing challenge the right of the British under the treaty to open up the area for free trade. Indeed, he did not ask Moor any questions at the trial, and when it came to making his defence, he denied obstructing trade. $^{\text {III }}$

Nana also had to answer the charges of violence. Moor testified that Nana's adherents had burned villages and captured people, and raided canoes belonging to the Itsekiri chiefs Dore and Dudu. He claimed that

${ }^{118}$ As for the second charge, relating to his failure to carry out the treaty provisions, Nana might have been charged under section 49 , which made it an offence wilfully or knowingly to act in contravention of any treaty as defined in the order; but the charge sheet made no such specification.

${ }^{19}$ Regina versus Nanna Alluma, FO 403/2 I 5, enc. in No. 71 \% , pp. 46B-46C.

${ }^{120}$ Exhibit 'A', FO 2/64, f. 346.

${ }^{\mathrm{I} 2 \mathrm{I}}$ Regina versus Nanna Alluma, $\mathrm{FO}$ 403/21 5, enc. in No. $7 \mathrm{I} *$, pp. 46K-46L. 
Nana had conducted regular slave-raids, so that, at the time of his defeat, he had 5,000 slaves. As further evidence of his violence, Moor described the decapitated bodies found in the creeks near Ebrohimi after the capture of the town. Evidence was also given, by Nana's own messengers, of his brutal execution of two men in his town, one for an alleged murder and the other for adultery. Much of this evidence did not relate to specific charges against Nana, who was charged neither with slave-raiding nor with murder, but related to the broader accusation that he had terrorised the country. He denied slaveraiding, claiming that it was customary to take people as security for a trust or debt. He also denied any knowledge of the decapitations. ${ }^{\text {I22 }}$ According to Nana's account, the disturbances which occurred in the middle of I 894 derived from a long-standing feud between his father and Dore's father, and had nothing to do with the British, with whom he claimed to have no quarrel.

There was no denying that he had assembled a considerable arsenal of weapons and fought the British after the Alecto had arrived. However, Nana sought to portray himself as a man who was constantly keen to make peace - witnessed by his hoisting a white flag - but was too frightened to submit to Moor. He claimed to have given orders that white men were not to be fired on, and that even when Ebrohimi was attacked, any firing was to be over the heads of the white soldiers, to frighten them off. As for the fatal exchange with the cutter, he claimed that the Africans had been fired on first, and that they had only seen that there were white men on the ship after the shots had been exchanged. Nana's defence strategy was clearly one designed not to challenge British authority, but to accept the premises of colonial authority and deny culpability. Nana did not have the benefit of a lawyer, either to present his case or to cross-examine the witnesses for the prosecution. Nor did he call any witnesses of his own: his defence consisted solely of a statement made to the court.

On 6 December, Sir Claude MacDonald gave the finding of the court. This was not a reasoned judgment, for MacDonald neither explained the nature and meaning of the charges, nor did he go through any of the evidence to establish whether the charges were made out in detail. Instead, he merely listed the four counts against

${ }^{\mathrm{I} 22}$ Regina versus Nanna Alluma, $\mathrm{FO}$ 403/2 I 5, enc. in No. 7I*, p. 46L. 
Nana and convicted him on all four. Taking into consideration the fact that Nana had not been 'on all occasions a free agent in the action taken', the Consul-General sentenced him to deportation for life from the Benin district 'to such part of the Niger Coast Protectorate as may be from time to time directed by the Court'. ${ }^{\mathrm{I} 3}$ At the same time, he confirmed Moor's proclamation under which his property was declared forfeited. MacDonald reported to the Foreign Office on I3 December that Nana had been deported to the Upper Cross River. $^{\text {I24 }}$

When the papers from the trial arrived at the Foreign Office, officials puzzled over the provisions of the Africa Order in Council, as applied to Nana's case. The main charge against him, so it appeared, was under section 48 of the Order, which made provision for a sentence of imprisonment and/or a fine. However, officials in Whitehall doubted whether MacDonald had any power to deport the chief, unless following the provisions of section IO2 - he had first been required to give security for good behaviour, and had then failed to comply. It was admitted that this was a debatable point, but the legal adviser at the Foreign Office took the view that, were the matter to go to the Privy Council, it might be held that there was no power to deport, in the way that MacDonald had. However, he thought the best advice was to 'let things slide' and take no notice of the official despatch. London would wait until the matter was raised, if ever. In the meantime, it was also agreed that it was unnecessary to put Nana's trial in print, since, by the middle of $\mathrm{I} 895$, 'it is not now probable that questions will be asked.' ${ }^{25}$

In June 1896 , still in detention at Old Calabar, Nana petitioned the Governor of Lagos to be allowed to live there. Consul-General Moor was not sympathetic to the application. He thought that Nana's punishment had served as a good example to others in the protectorate, and the good would be undone if he were allowed to live in Lagos, which would soon be easily accessible from Benin. Moor wanted him to be removed to the Gold Coast, 'where there is proper accommodation for looking after natives in his position'. In Moor's

\footnotetext{
${ }_{123}$ Regina versus Nanna Alluma, $\mathrm{FO}{ }_{403} / 2 \mathrm{I}_{5}$, enc. in No. $7 \mathrm{I}^{*}$, p. $46 \mathrm{~N}$.

${ }^{124}$ Nana's conviction was followed by the trial of seven of his associates on similar charges, six of whom were convicted. Regina versus Nanna Alluma, FO 403/2I 5 , enc. in No. $7 \mathrm{I}^{*}$, p. $46 \mathrm{P}$.

${ }^{225}$ Minute by William Edward Davidson, dated I 8 June I 895, FO 2/64, f. 292.
} 
view, it would be a good thing to let 'the semi-civilized Chiefs' of the coastal region know that they would be removed from the protectorate altogether if they took up arms against the government. ${ }^{\mathrm{I} 26}$ The Foreign Office duly asked the Colonial Office whether it would authorise this. ${ }^{127}$ The instructions were given, and the relevant ordinance passed at the Gold Coast. ${ }^{\mathrm{I} 28}$ The fact that this was all done by legislative fiat - rather than by following the procedures provided for under the Colonial Prisoners Removal Act and the Foreign Jurisdiction Act - might suggest that officials remained aware of the slender legal basis on which Nana's removal to Old Calabar rested.

As an African potentate seeking to protect his position as a middleman in trade from British encroachments, Nana Olomu's position was much like that of Jaja. Unlike the king of Opobo, however, he was treated as subject to British jurisdiction and tried in a consular court. If Nana was regarded as sufficiently sovereign to sign a treaty of protection, his sovereignty was not sufficient to make British officials feel that - like Abdullah - he could not be put on trial. By the time that Nana was tried, the very idea of a protectorate was changing. The traditional legal view that a protecting power had extraterritorial jurisdiction only over its own subjects and outsiders who also enjoyed its protection ${ }^{\mathrm{I} 29}$ had given way - at least in post-Berlin Africa - to a view (incorporated in the Africa Order in Council) that jurisdiction was also acquired over anyone residing within the protected area, if the consent of the ruler or community could be implied. ${ }^{130}$ In Nana's case, the Foreign Office's officials simply assumed that the wider protectorate - which had been extended and renamed the Niger Coast Protectorate in 1893 - had jurisdiction over him, which did not derive from his own consent, whether express or implied. It was a contentious interpretation of the law, and one which would not be followed four years later by the Colonial Office and the Law Officers in London, when considering the case of Bai Bureh in Sierra Leone. If there

${ }^{126} \mathrm{FO}_{4} \mathrm{O}_{3} / 234$, No. I6, p. 27 at p. 28. Officials in London noted that 'Moor's reasons are strong against the Chief's going to Lagos': FO 2/IOI, f. I24v.

${ }^{127} \mathrm{FO}_{403} / 234$, No. 29, p. 42.

${ }^{128}$ FO $403 / 234$, No. 50, p. 6I; No. 58, p. 65; Gold Coast Ordinance Io of I 896.

${ }^{129}$ Johnstone, Sovereignty and Protection, pp. 66-68.

${ }^{130}$ For the provision of the I 889 Order in Council, see Hodges, Consular Jurisdiction, p. 93. See further W. E. Hall, A Treatise on the Foreign Powers and Jurisdiction of the British Crown (Oxford, Clarendon Press, I894), p. 2 I3. 
were questions to be raised about the basis of the jurisdiction in Nana's case, there were also further questions to be raised about the form of the trial, the nature of the charges against him, and the sentence imposed. This was not the rule of law in action; it was a form of lawfare, designed to impress both on Nana and on his followers that they were now subject to British jurisdiction; and one which, in the end, needed the same kind of formal authentication by ordinance as had been used against Jaja.

\section{Ovonramwen}

The third important ruler to be removed in this region was the Oba of Benin, Ovonramwen. The kingdom of Benin, over which he ruled, had been the dominant political authority in the region in the middle of the nineteenth century, before internal divisions and growing British influence on the coast began to weaken its authority. ${ }^{\mathrm{I} 3 \mathrm{I}}$ For most of this period, the British showed little interest in exploring Benin, even though they had a well-established trade on the lower reaches of the Benin river. ' $[\mathrm{N}]$ othing can be said in favour of Benin', Richard Burton (then consul at Fernando Po) wrote in I 863 after visiting the city, 'the place has a fume of blood, it stinks of death. ${ }^{\mathrm{I} 32}$ No British official would return for nearly three decades. However, once the scramble for Africa got under way, interest grew in opening up trade routes to Benin City. In May I885, Vice-Consul David Blair was sent with one of Hewett's treaties, but he fell ill en route and died before he could get there. ${ }^{133}$ Three years later, Harry Johnston reported that, with the recent accession of Ovonramwen as the new Oba, Benin City 'appears to be more open to European influence than formerly'. ${ }^{\text {I34 }}$

${ }^{\text {I3I }}$ See Ryder, Benin and the Europeans, ch. 7; Philip A. Igbafe, 'The Fall of Benin: A Reassessment', Journal of African History, vol. II:3 (I970), pp. 385-400; P. A. Igbafe, Benin under British Administration: The Impact of Colonial Rule on an African Kingdom 1897-I938 (London, Humanities Press, I979); and Robert Home, City of Blood Revisited: A New Look at the Benin Expedition of I 897 (London, Rex Collings, I982).

${ }^{132}$ Richard Burton, 'My Wanderings in West Africa', Fraser's Magazine, vol. 67 (March I863), pp. 273-289 at p. 287.

${ }_{133}$ Ryder, Benin and the Europeans, p. I67; FO 403/7I, No. 6I, p. 70.

${ }^{134}$ H. H. Johnstone, 'A Report on the British Protectorate of the Oil Rivers', FO 84/ I 882, f. I36. Sir Percy Anderson reported on Io September I 888 that Ovonramwen had told Johnston that he would forcibly resist any attempt to incorporate his territory into the Lagos colony: $\mathrm{FO} 403 / 76$, No. I 82, p. 216 at p. 217. 
However, nothing more was done until I 890 , when an unsuccessful attempt was made by Consul Annesley to get Ovonramwen to sign a treaty. It was not until March I892, when Gallwey visited the city, that a treaty was obtained. On this occasion, the king proved reluctant to commit himself, but conceded after Gallwey threatened to leave, and not to return 'as a friend'. The king, in full ceremonial dress for the occasion, agreed to the standard form treaty, though he did not himself touch the pen which made the cross on his behalf. ${ }^{\mathrm{I} 35}$

Although MacDonald told the Foreign Office in May I 892 that 'trade, commerce and civilization' in the area were paralysed by the fetish government, he had high hopes of opening up 'this rich and most important' territory. ${ }^{\mathrm{I}}{ }^{6}$ Gallwey also thought that the treaty would be the foundation of a new order of things. In his view, two things stood in the way. The first was the power of the fetish priests, which needed to be broken before trade would be fully open. The second problem was that Ovonramwen exerted a tight control on trade in the Benin country, imposing taxes, forbidding trade in many products and frequently stopping trade for reasons which were hard to fathom. ${ }^{137}$ In the event, little progress was made in opening up the area. Although the British had 'hopes that the lesson given to Chief Nana in Benin River would lead to the King of Benin city receiving a Representative', ${ }^{138}$ efforts to open up communication with Benin met with little success. When ViceConsul Copland-Crawford was sent in August I895 to open up the district for trade, Ovonramwen sent a messenger saying he could not receive any white visitors during this time of traditional customary celebrations. ${ }^{\mathrm{I}} 39$ The king also continued his old practices in matters of trade by placing a 'ju-ju' on the most profitable items - imposing a death penalty for trading in them - and also closing his markets until he was paid presents. In Moor's view, Ovonramwen was acting flagrantly in breach of the treaty, and the first opportunity should be taken to open up the country, 'if necessary, by force'. ${ }^{\mathrm{I} 4 \mathrm{O}}$ The Oba had good reason to fear British bellicosity. The previous November, he had sent messengers to the consulate to ask why Nana's towns had been destroyed only to be told that it was because Nana had disobeyed the orders of the Queen

\footnotetext{
${ }_{35} \mathrm{FO}_{403 / \mathrm{I}} \mathrm{I}$, enc. I in No. I64, p. I I 2 ; enc. 2 in No. I64, p. I I4.

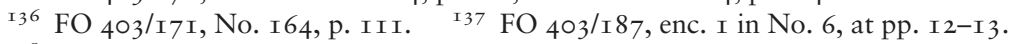

${ }^{13} 8$ FO 403/234, No. I4I, p. I 5I. ${ }_{139}$ FO 403/2I6, enc. in No. IO8, p. 228.

${ }^{\mathrm{I}} \mathrm{FO}_{403} / 2 \mathrm{I} 6$, No. IO8, p. 227 at p. 228.
} 
and not respected his treaty. ${ }^{\mathrm{I}}{ }^{\mathrm{I}}$ Mistrustful of the men on the ground, the Oba told Copland-Crawford that he wanted to send messengers to London, an attitude which MacDonald felt could only be attributed to the influence of 'educated natives' from Lagos or elsewhere. ${ }^{\text {I42 }}$ Nonetheless, MacDonald urged caution before bellicose action was resorted to. He suggested that patient efforts should be made to open up communication with the king over the coming dry winter months; only if this failed should an expedition be sent in the following dry season. ${ }^{\mathrm{I}}{ }^{\mathrm{C}}$

However, when MacDonald left West Africa in February I 896 to become minister to China, he was succeeded by men of a more bellicose frame of mind. When Ovonramwen stopped all trade with the Itsekiri in April I 896, ${ }^{\text {I44 }}$ the new Consul General Moor concluded that the policy of peace had failed, and that preparations should be made for an expedition to remove the king. ${ }^{45}$ When Moor went on leave to England, his acting replacement as Consul General, James R. Phillips, also recommended deposing the king, who was still blocking trade. In November, he requested permission to launch an expedition the following February to unstool the king, and set up a new native council in its place. ${ }^{\mathrm{I} 6}$ Having consistently taken a much more cautious approach to this matter, ${ }^{\mathrm{I}} 47$ the Foreign Office concluded (after consulting the Colonial Office and the War Office) that the necessary troops could not be spared. Phillips was duly instructed by telegram on 8 January I 897 to postpone the proposed expedition for a year. ${ }^{\mathrm{I}}{ }^{8}$

By then, Phillips was dead. Without first consulting his masters in London, he set off from Sapele on 2 January with 9 Europeans and 220 African carriers on a mission to Benin City to negotiate with the king.

${ }^{\text {I4I }}$ FO 403/2I6, No. I30, p. 243. ${ }^{142}$ FO 403/216, No. I30, p. 243.

${ }^{\mathrm{I}} 43$ His view was shared by the Foreign Office: $\mathrm{FO}_{403} / 2$ I 6, No. I 5 I, p. 252.

${ }^{\mathrm{I}} 44$ See Moor to Hill, 6 June I896, FO 2/IOI, f. II7, quoted in Ryder, Benin and the Europeans, p. 28I. For details, see FO 403/234, No. I39, p. I45 at pp. I46-I47; FO $403 / 248$, enc. in No. 7, p. 7.

${ }^{145}$ Moor to Foreign Office, I4 June I896, FO 2/IoI, f. I43.

${ }^{146} \mathrm{FO} 403 / 234$, No. I39, p. I 45 . Moor concurred with this plan: No. I44, p. I 5 I.

${ }^{\mathrm{I}} 47 \mathrm{FO} 403 / 234$, No. $33^{*}$, p. 43 . Hill minuted, 'our men should keep their heads \& not burst into "punitive expeditions" on every pretext. The King of Benin may have to be dealt with but it should be set about with care $\&$ with a sufficient force $\&$ at our own time': FO 2/IOI, f. I49v.

${ }^{\mathrm{I} 48} \mathrm{FO}_{403} / 248$, Nos. I3-I4, p. I3. 
On being given notice of this intended peaceful visit, Ovonramwen replied that he could not meet Phillips for at least a month, since he was engaged in customary ceremonies. Even then, he would only be prepared to meet Phillips and one Itsekiri chief, since he had heard of the white men going all over the country and taking the Chiefs prisoner'. ${ }^{\text {I9 } 9}$ The party spent the night Ughoton, where the friendly Itsekiri chief Dore - Nana's nemesis - warned Phillips that it would 'be certain death to go'. Phillips decided nonetheless to proceed, although he sent back the drum and fife band of the Niger Coast Protectorate Force, which had originally accompanied the party, since their military uniforms might alarm the king of Benin. On 4 January, the party was ambushed and all the whites save 2 were killed, along with I 24 Africans. ${ }^{150}$ Reports were later received from the Principal Medical Officer that the decapitated bodies of some of the Europeans were later found in Benin City, but this information was suppressed to avoid distress to their relatives. ${ }^{\mathrm{III}}$

This ambush - which attracted considerable media attention in Britain $^{152}$ - changed policy. The decision was taken to send an expeditionary force as soon as it could be mustered, to rescue any possibly surviving members of Phillips's party, to capture Benin city, and to punish the king for this outrage. ${ }^{53}$ In Gallwey's view, 'the punishment to be inflicted' for the outrage 'cannot be too severe'. It would also have the effect of removing an obstacle to British expansion, for 'the destruction of Benin city, the removal and punishment of the King, the punishment of the fetish priests, the opening up of the country, \&c, will prove a wonderful impetus to trade in this part of the Protectorate'. ${ }^{154}$ The expeditionary

${ }^{1} 49 \mathrm{FO}_{403} / 248$, enc. I in No. I26, p. 89.

${ }^{1} 50$ FO $403 / 248$, No. I25, p. 87. The two survivors were District Commissioner Ralph Locke and Captain Alan Boisragon. On the events, see Alan Maxwell Boisragon, The Benin Massacre (London, Methuen \& Co., I 897).

${ }^{\text {I }}$ I Moor to Foreign Office, I 8 March I 897, FO 2/I 2 I f. 257, with enclosures.

${ }^{152}$ As the Manchester Guardian explained (I 2 January I897, p. 7), '[m]ost of the captives were well known in official and club circles in London.' For the coverage of the events in the British press, see Annie E. Coombes, Reinventing Africa: Museums, Material Culture and Popular Imagination in Late Victorian and Edwardian England (New Haven, Yale University Press, I994), pp. I I-22.

${ }^{15} \mathrm{FO}_{403} / 248$, No. 54, p. 29; No. 92*, p. 44A. See also Moor's interview, The Times, I6 January I 897, p. 5 .

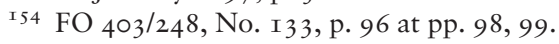


force advanced rapidly, reaching Benin City on 18 February. It took much of the day to capture the city, at a cost (to the British forces) of nine lives. By the time it was taken, the king and all the inhabitants had fled, leaving only a mass of sacrificial corpses. ${ }^{\text {I55 }}$ From a mile and a half out, the forces encountered the disembowelled bodies of people freshly sacrificed to prevent the conquest of the town. Having entered Benin, Moor (who had left England as soon as news of the attack reached him) described 'the horror of this most terrible city', with the stench of decomposing bodies in open pits and altars covered with streams of dried blood. In one of the pits, under a pile of bodies, they found a servant of one of the traders who had been in Phillips's party. 'All about the houses and streets are dead natives, some crucified and sacrificed on trees, others on stage erections, some on the ground, some in pits', wrote Felix N. Roth, a surgeon accompanying the party, 'by God! may I never see such sights again!' ${ }^{156}$ Moor concluded that it was 'imperative that a most severe lesson be given the Kings, Chiefs, and Ju Ju men of all surrounding countries, that white men cannot be killed with impunity, and that human sacrifices, with the oppression of the weak and poor, must cease'. ${ }^{\text {I }} 57$

Moor's men destroyed the sacrificial altars and began burning the chiefs' compounds. He determined to level the city entirely, to forestall any future rebuilding on this site. He also seized a large number of bronze castings, and ivory and wood carvings from the city, some of which were sold to help pay the expenses of the expedition, and many more of which would find their way into the British Museum. ${ }^{158}$ On the third day, four messengers arrived from the king, asking for a palaver. Moor gave a non-committal answer but left a way open for the chiefs to come in. He had already planned to settle matters 'by native palaver, country custom being very strict in demanding an eye for an eye and a tooth for a tooth'. ${ }^{159}$ At the end of March, by which time eighteen of the principal chiefs had come in, Moor

${ }^{155}$ H. Ling Roth, Great Benin: Its Customs, Art and Horrors (London, Routledge 1968 [1903]), Appendices, xii.

${ }^{156}$ Roth, Great Benin, Appendices, viii, x. $\quad{ }^{157} \mathrm{FO}_{403} / 248$, No. I 54, p. I4I at p. I 44.

${ }^{15} 8$ See Coombes, Reinventing Africa, ch. I; and Mary Lou Ratté, Imperial Looting and The case of Benin, University of Massachusetts MA thesis, 1972.

${ }^{159} \mathrm{FO}_{403} / 248$, No. I 54, p. I4I at p. I 44. 
elaborated on his plan. He would hold a court under native custom to try the men responsible for the massacre. The aim was to demonstrate to the local people that the king and the chiefs could not perpetrate such acts with impunity. This would help undermine the authority of the king and the chiefs in the eyes of the people, allowing their place to be taken by a native council under government supervision. ${ }^{\mathrm{I}}{ }^{60}$

By early June, thirty chiefs had sworn 'submission to the rule of the white man' in the traditional manner. ${ }^{\text {6I }}$ ' $[\mathrm{H}]$ aving become sick of his unaccustomed roaming bush life', the king himself returned to Benin City on 5 August, accompanied by some 800 followers. In full royal dress and before a crowd of I,०o०, he made his submission to the Acting Political Resident, Captain E. P. S. Roupell in the traditional manner putting his forehead on the ground - and was informed that he had been deposed. ${ }^{162}$ Moor now proceeded to Benin City, where he assembled the king and seventy chiefs for a palaver on I September. It was held in the court house of the consular court, which had been set up at Benin under the Africa Order in Council in July. ${ }^{{ }^{6} 3}$ Those present included Moor, Roupell and Captain Carter (the officer commanding the troops), nine members of the newly established native council, and sixty other chiefs, besides the king. 'I am not going to talk this palaver in the white man's fashion, but I am going to talk it in the native fashion', Moor began, 'and we are going to settle by your own custom and law.' He also made it clear that the Africans were not on trial for having taken up arms. 'The white man has no palaver with King and Chiefs because they fought for their country and lost', he told them, 'Every man that fights for his country is right.' Instead, the aim was to find out who was responsible for the murders and to deal with them according to native law. ${ }^{164}$

${ }^{160} \mathrm{FO}_{403} / 248$, No. I98, p. 204. ${ }_{\text {I6I }} \mathrm{FO}_{403 / 249}$, No. I22, p. I43 at p. I44.

${ }^{162}$ Roth, Great Benin, Appendices, xiii-xiv.

${ }^{163}$ FO 403/249, No. 30 p. 23, referring to Moor's despatch of 8 June I 897 (FO 2/I 22, f. 54). In this Moor said a court needed to be established in Benin City as many Africans were coming there from Lagos 'and the protected provinces' and had 'to be dealt with as either British subjects or British protected subjects under the Order'. The Foreign Office wrote that the expression to be used was 'British-protected persons', not 'British-protected subjects'.

${ }^{16} \mathrm{FO}_{403 / 250}$, enc. I in. No. 203, p. I98. See also the report of the trial in Roth, Great Benin, Appendices, xii-xviii. 
Rather than taking the form of a trial, in which particular defendants were charged with particular offences, and in which prosecution and defence would be conducted by lawyers, this palaver took the form of an inquiry into who had instigated the massacre, and what part the king played in it. On the first day, evidence was given by three 'boys' - men in the retinues of Obahawaie and Obassieki. They identified six chiefs as having been present when the white men were killed, and who gave orders to kill them: Obaiuwana, Obahawaie, Usu, Ugiagbe, Obadesagbo and Ologbosheri. Only four of these men were in court, for Obadesagbo had died before the trial began, while Ologbosheri was still at large. At the end of the first day, the four men were taken into custody. Moor told them that if they were able to show that it was not their palaver, he would let them go; but otherwise, they would be dealt with by native law. By the time the court reconvened, Obaiuwana had killed himself by cutting his throat.

The first of the chiefs to speak was Obahawaie. He recounted that, ever since the war against Nana, it had been feared that the whites would make war on Benin. He blamed the massacre on bellicose chiefs rather than the king, who was described as a somewhat reclusive figure. According to Obahawaie, when the king was told that the whites were bringing war, he told his chiefs not to fight them, but to allow them to come. However, the chiefs, led by Ologbosheri and Iyasheri, rejected this and gave the orders to fight. When Obahawaie questioned them - having heard the whites were unarmed - he was himself threatened with death unless he joined the attack. Usu told a similar story of attempting to persuade the more bellicose chiefs not to kill the whites, as the king had forbidden it. Other witnesses related how Ologbosheri had said that it would be folly not to kill the white men, since they would themselves be killed if this were not done. The evidence of these chiefs clearly placed responsibility for the ambush on Ologbosheri and Iyasheri (who had also killed himself after his arrest). ${ }^{165}$ At the end of the hearing, Ovonramwen himself spoke. He claimed to be a friend to the white man, and that he had urged his chiefs 'not to fight the white man, even if he brought war'. ${ }^{\text {66 }}$

${ }^{165} \mathrm{FO}_{403} / 250$, No. 203 , p. I95, referring to him as Iguobasoyemi.
${ }^{166} \mathrm{FO}_{403 / 250}$, enc. I in. No. 203, p. 203 . 
By the end of these hearings, Moor came to a number of conclusions which he reported to the Foreign Office. After the fall of Nana, the king and chiefs of Benin had expected their country to be taken over, and had determined to resist. They had stationed people on the road from Ughoton to watch any attempt by the British to approach. Once they had learned of Phillips's approach, a force of I,००० warriors was assembled 'for the purpose of repelling any attempt to take the country by force'. ${ }^{167} \mathrm{He}$ accepted that the king himself did not want to fight the whites, but was overruled by a majority of the chiefs. Moor realised that the Africans might have suspected that the unarmed party of whites had weapons, but also considered that the attackers might have been motivated in part by a desire for plunder. Giving his judgment to the court, Moor began by invoking native law and custom, which held (he asserted) that, if a king was killed, a king must die, and if a chief was killed, a chief must die. In this case, both Phillips - 'the King of the white men' - and his deputy had died. Although this seemed to suggest that Ovonramwen and his second man, Chief Aro, should die, Moor qualified it by adding that he accepted 'there is some doubt as to your action in killing the white men'. In his judgment, the king and all his chiefs could not be seen as murderers, since they thought that the whites had come to make war on them, and thought they were fighting for their country, something Moor regarded as an honourable thing. However, since those chiefs who took part in the ambush could see that the whites were unarmed, they had to be condemned as murderers. While Ugiagbe was spared, since he was only a 'small boy' who did what he was ordered, Obahawaie and Usu were sentenced to death, and were shot the following morning. Moor also announced that Ologbosheri would suffer the same penalty, and that until he was brought in, he would hold the lives of five chiefs as hostages for his crime. ${ }^{\text {168 }}$

The trial reflected an odd form of hybrid legalism. Sitting in the room of the consular court, the Consul General arrogated to himself the right to try by what he took to be native law, and to order an

${ }^{167} \mathrm{FO} 403 / 250$, No. 203, p. I95 at p. I96.

${ }^{168}$ Ologbosheri was captured in June I 899, and was tried in Benin City in another 'native court', presided over by Moor. The judgment, given by the chiefs, was that 'Ologbosheri was not sent to kill white men, and we therefore decide that according to native law his life is forfeited.' PP I 899 (c. 9529 ) LXIII. 395 at p. 22. 
execution by British troops. If this showed echoes of Langalibalele's experience, Moor could not claim the right to native jurisdiction which Governor Pine had as the statutory 'supreme chief'. This was another trial without lawyers, and one in which no formal charges were laid, even if it was clear that the men were accused of participating in murder. In contrast to Nana's case, there was no notion that this chief, who had signed the same treaty as Nana - albeit without striking out any clauses - was liable to prosecution under protectorate law for violating the terms of the treaty, and resisting with arms. Indeed, Moor saw this as something honourable. At this stage, it was clear that he did not wish to treat Ovonramwen in the same way that Nana had been treated.

Three days after the executions, another meeting was held in the consular court with the king and the native council and chiefs. Ovonramwen had little to say, telling Moor, 'I have only come to beg you.' In fact, the purpose of this meeting was not to try the Oba, but to inform him of the new political dispensation in what had been his kingdom. Moor told the assembled chiefs that Ovonramwen was no longer king: 'There is only one King in the country, and that is [the] white man.' ${ }^{169}$ After explaining the new administrative structure, he informed Ovonramwen that he would henceforth be chief of Benin City, with the same rank as other chiefs. During the time that would be required to allocate villages to Ovonramwen to support his chiefdom, he was to accompany Moor to other places in the protectorate, to see how they were governed. Rather than being exiled, he would be educated in how to be a good chief, and one who was a friend to the white man. Ovonramwen agreed to this, and was told to return two days later at $9 \mathrm{am}$. At the same time, he was warned that if he made any attempt to leave the city, he would be captured and hanged.

Ovonramwen did not appear at the appointed time on the morning when he was due to return. When people were sent to fetch him, he ran away, only to return when persuaded by his followers. Later in the day, when a group of soldiers was sent to his house to collect him, he again ran away to a nearby village, where he was later found hiding in a bush

${ }^{169} \mathrm{FO}_{403} / 250$, enc. I in No. 203 at p. 205. 
hut. ${ }^{170}$ By now, Moor had lost patience. 'You are now in the position of a prisoner', he told the Oba, 'and you will be treated as any other prisoner.' Though he had not been given any trial, he was given a sentence of exile: 'from this day, and for the rest of your life, you have done with your people and with your country'. ${ }^{17 \mathrm{I}} \mathrm{On} \mathrm{I}_{3}$ September, Ovonramwen was moved to Ughoton, where he was transferred to a vessel to take him to Old Calabar. Only two of his eighty wives were permitted to accompany him, and two followed later. When Moor's report reached the Foreign Office, Sir Clement Hill, head of the African department, commented that he had acted 'with great care and judgment' and proposed that his conduct be cordially approved. Hill, a man who had spent thirty years at the Foreign Office and who had no background in law, was untroubled by the lax nature of the proceedings. 'I do not suppose that any one will raise questions in the future about it', he told Salisbury, 'unless it is some rabid Aborigines protectionist.' ${ }^{\text {I72 }}$

Ovonramwen remained in exile until his death at the beginning of I9I4. It was not until May I9II, however, that any ordinance was passed to legalise his removal from Benin. After living quietly in exile in Old Calabar, in February r9 I I Ovonramwen petitioned the Governor of Southern Nigeria, Sir Walter Egerton, to be allowed to return to his home. When permission was refused, the ex-king threatened to bring proceedings in the Supreme Court. The ordinance was duly passed, as Attorney General A. R. Pennington explained, '[i]n order to guard against any eventuality', though 'there is no intention of using this power if Overami remains quietly at Calabar'. ${ }^{173}$ The measure attracted the attention of the radical Liberal MP Sir William Byles in the House of Commons. Byles criticised the fact that, in what was meant to be an empire of freedom, a Governor was being given 'the power to do anything he pleases', and that the writ of habeas corpus was being denied to his 'victims'. ${ }^{\text {I74 }}$ The Secretary of State (Harcourt) replied rather

\footnotetext{
${ }^{170}$ See Ryder, Benin and the Europeans, p. 294.

${ }^{17 \mathrm{I}} \mathrm{FO}{ }_{403 / 250}$, enc. 2 in No. 203, p. 208 at p. 209.

${ }^{172}$ Minute dated I 8 October I $897, \mathrm{FO}_{2} / \mathrm{I} 23$, f. 74 . The approval was duly sent: FO 403/250, No. 306, p. 313 .

${ }^{173}$ Report of A. R. Pennington, 8 May I9II, CO 520/I03/I 845 I, reporting on the Overami Detention and Deportation Ordinance, No. I I of I9I I.

${ }^{174}$ Parl. Debs., 5th ser., vol. 28 (20 July I9I I), col. I 3 I 5.
} 
airily that he thought that the ordinance was unnecessary, but had only been passed 'to clear up a technical doubt, because I believe the ex-king has suddenly taken, under legal advice, some technical point as to past action'. ${ }^{175}$

Another ruler whose actions obstructed British trade in the area, Ovonramwen's treatment differed both from Jaja's and from Nana's. Although he had signed Hewett's treaty, and although a consular court had been set up in Benin City, he and his chiefs were not tried under consular jurisdiction for the deaths of the Europeans. Instead, Moor conducted a hearing under what he perceived to be native law although, unlike Governor Pine of Natal, he had no clear sense of the source of his power to apply that law, or any guide to what that law might have been. In this informal 'trial' of murder, Moor acquitted Ovonramwen, but then imposed a political penalty - his deposition and dethronement - which was unrelated to any charges. The further penalty of exile which was imposed after the king had tried to run away was equally unfounded in any law or possible legal justification.

\section{Conclusion}

In many ways, Jaja, Nana and Ovonramwen had very similar experiences at the hands of the British. Each was a king or chief who had signed one of Hewett's protection treaties, and each had sought to protect his markets by resisting British encroachments. It was for this resistance to British expansion that these rulers were deposed and deported. In each case, an ad hominem ordinance was used to authorise their detention, though in each case the ordinance was passed at different stages in the process. In the case of Jaja, who had the support in London of the merchant house of Miller, Brother \& Co., legal cover was provided as soon as there was any suggestion that a legal challenge might be brought. In Nana's case, an ordinance was passed only when the decision was taken to move him from the Niger Coast Protectorate to the Gold Coast, whereas Ovonramwen was kept at Calabar for fourteen years before the ordinance was passed, as a kind of insurance, to legalise his deportation. In their cases, the authorities were clearly confident that there was no risk of habeas

${ }^{175}$ Parl. Debs., 5th ser., vol. 28 (20 July I9I I), col. I347. 
corpus proceedings being brought while they remained in the protectorate, for these men had few supporters in London to take up their case. It was only when this fear became real in Ovonramwen's case that the authorities reacted.

In each case, their fate was determined not by the rule of law, but by the exercise of power, formally endorsed by ordinances. From the point of the three rulers, they had committed no offence against British jurisdiction, but had simply resisted British claims to open up trade in their areas. They were defending their rights against aggressive encroachment by an external power. Jaja was the most articulate defender of this position: as a ruler who had both signed a treaty with the British reserving his rights, and who had not come into armed conflict with British forces, he presented legal arguments which the British struggled to answer. In an era of changing Western perceptions of protectorates, his claim to be an independent ruler still had some political purchase, at least at the Foreign Office, which was initially inclined to treat this more as a matter of international law than as a matter of local discipline, and engage with his arguments. It was this which explains the form of inquiry which was held to investigate his alleged breaches of his treaty obligations. However, in this case, the interest in engaging with Jaja's legalism soon gave way to pressure from local officials and traders, who simply wanted this troublesome chief removed. As in Abdullah's case, the inquiry served as a political justification to enact the kind of legislation used against Napoleon, as a means to assert sovereignty and jurisdiction over a ruler who stood in the way of British interests.

With the Niger Coast Protectorate having been established, the Foreign Office appears to have been more confident in its power to deal summarily with Nana, who (unlike Jaja) had actively resisted the British military in an area where they now claimed jurisdiction. Nana was neither treated as an independent ruler, nor did he assert his rights as one, in the manner of Jaja. Where Jaja had drawn specific attention to what he had - and what he had not - agreed in the I884 treaty, Nana's reservation of his rights was simply ignored. However, Nana was not simply removed by ordinance, in the way that political prisoners in the Gold Coast and Sierra Leone were simply removed. Instead, in the protectorate, officials elected to use a form of consular trial to portray Nana as a rebel against British authority. This was to 
give a signal to other local rulers that troublesome chiefs who were resisting an authority they now had to obey would be duly punished. If this was a form of lawfare, it hardly complied with metropolitan ideas of the rule of law, given the flaws both in the charges against Nana and in the procedures used at the hearing. However, consular officials were not worried about ensuring that the spirit of the common law was followed: they wanted to use law to convey other messages about British power, and they faced very few restraints from their political masters in the Foreign Office in doing so. In the case of Ovonramwen and his chiefs, protectorate officials once more asserted their jurisdiction to conduct a criminal hearing - physically in the consular court - again in order to give signals about the nature of British power. In this case, the form of 'lawfare' used was quite different from that used in Nana's case, with Ralph Moor purporting to apply against the chiefs a native law which he had no authority to administer. This was yet a further step away from English conceptions of the rule of law. Once the trial was over, and the two chiefs executed, Moor clearly felt he had sent all the 'legal' signals which were needed: so that, when Ovonramwen was exiled, it was by simple administrative fiat, with no law at all being applied. 